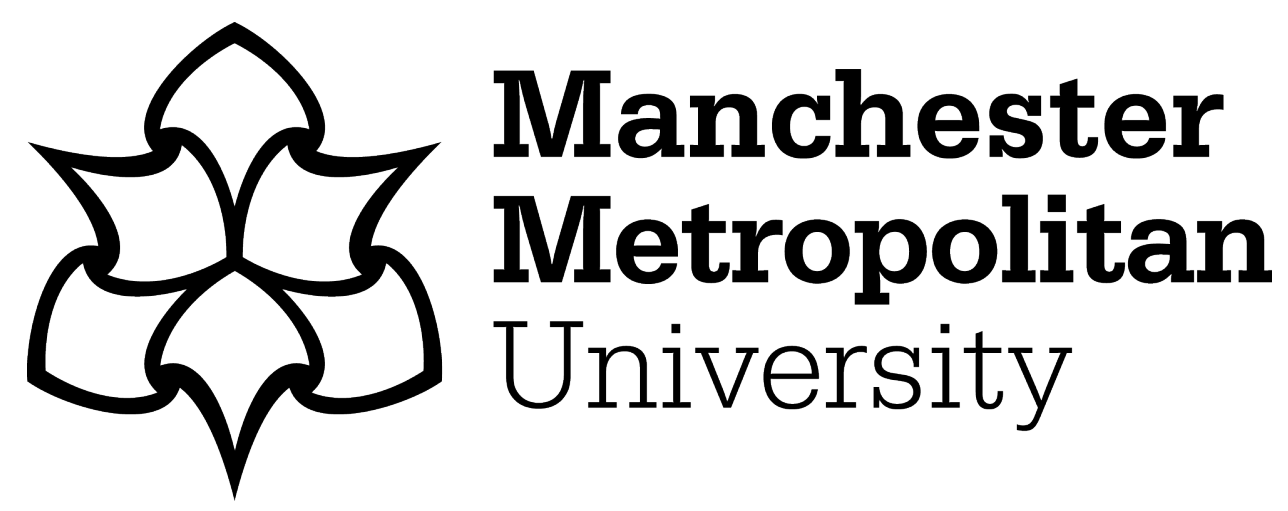

Leal, Walter, Saari, U, Fedoruk, M, lital, A, Moora, H, Klöga, M and Voronova, $\mathrm{V}$ (2019) An overview of the problems posed by plastic products and the role of extended producer responsibility in Europe. Journal of Cleaner Production, 214. pp. 550-558. ISSN 0959-6526

Downloaded from: https://e-space.mmu.ac.uk/622465/

Version: Accepted Version

Publisher: Elsevier

DOI: https://doi.org/10.1016/j.jclepro.2018.12.256

Usage rights: Creative Commons: Attribution-Noncommercial-No Derivative Works 4.0

Please cite the published version 


\title{
An Overview of the Problems Posed by Plastic Products and the Role of Extended Producer Responsibility in Europe
}

\author{
Walter Leal Filho \\ Journal of Cleaner Production, 214, pp. 550-558. https://doi.org/10.1016/j.jclepro.2018.12.256
}

\begin{abstract}
Plastic products are easy and convenient for our everyday use, but their negative impacts on human health and the environment cannot be overlooked. The negative impacts and effects of plastic waste are now widely known and have been subject of much recent media coverage, both in Europe and on a global level.

Faced with increasing amounts of plastic waste, the European Union as a whole and many European governments in particular, are currently revising the policy options available to cope with the problem. One of the tools which may be deployed with a view to reducing the pressures posed by plastic waste, is the Extended Producer Responsibility principle. It is considered to be one of the major waste management policy instruments that support the implementation of the European waste hierarchy. Its application may assist in fostering the collection and recycling of waste streams that contain plastic. This paper presents an overview of the problems posed by plastic waste, and outlines their environmental dimensions. It discusses the role of the Extended Producer Responsibility principle and provides some recommendations that may be useful in enhancing extended producer responsibility.
\end{abstract}

Keywords: Plastic; Plastic Waste; Europe; Extended Producer Responsibility

\section{Highlights:}

The production of plastic waste in Europe is increasing Many plastic-related policies across Europe are not satisfactory

The environmental impacts of plastic disposal are significant and deserve immediate action Extended Producer Responsibility can assist in reducing the scope of the problem

\section{Introduction: plastic as a valuable material and problematic waste}

Plastics are synthetic or semi-synthetic organic polymers that are lightweight, strong, durable and low cost (Van Eygen, et al 2017). For these characteristics they are used for the production of a very wide range of products and they have rapidly moved into all aspects of human life. Plastics cover a wide range of synthetic polymeric materials (such as polypropylene, polyethylene, polyvinyl chloride, polystyrene, nylon, and polycarbonate) producing large spectrum of different final products. .

Most plastics are derived from non-renewable fossil feedstocks (e.g. natural gas, oil or coal). Also, renewable or bio based resources such as plant proteins, plant oil or carbohydrates e.g. cellulose, starch, lignin and many others, can be used for plastic production (de Vargas Mores et al, 2018). Another alternative to fossil-based plastics production is deriving the key plastic building blocks, hydrogen and carbon from electricity. This can be done through electrolytic processes combined with carbon capture and utilization technology (Palm et. al, 2016). But at the moment the biobased plastics represent a very small share of the market and another alternative methods are relatively unexplored. Thus, plastic materials can be classified into various types commonly grouped into three broad categories based on their physical characteristics (Bourguignon, 2017): 1) thermosets (hard plastics that cannot be re-melted and reshaped), 2) thermoplastics (that can be 
re-melted back into a liquid and reshaped or recycled repeatedly) and 3) elastomers (soft elastic plastics).

Plastic as a material helps to tackle a number of the challenges in our society. Innovative, lightweight plastic materials in vehicles or high-performance insulation materials help to save energy and reduce $\mathrm{CO}_{2}$ emissions. Plastics, due their durability, weight and cost, are particularly effective in packaging applications. For example, in packaging, plastics used to protect and keep food in safe reducing amount of food waste.

The applications of plastics are extensive and as a result, their production has been showing a continuous growth over the past 50 years. And is expected to double in the next 20 years (World Economic Forum et al., 2016; Gu et al., 2017). Approximately 335 million tons of plastics were produced in 2016, 18\% of it having been produced in Europe (PlasticsEurope, 2018).. The European plastics industry includes producers of raw plastic materials, converters of plastics, recyclers of plastics and plastics machinery manufacturers. The industry generated total annual sales of EUR 350 billion in 2016 and ranks seventh in Europe in industrial value-added contribution (PlasticsEurope, 2018).

Within the European single market, Germany is the largest producer of plastic parts and components, with sales of over EUR 90 billion (Germany Trade and Invest, 2017). Its share accounts for $37 \%$, followed by France (17\%) and Italy (11\%). Germany is also the largest European exporter (31\% of all European exports), followed by Italy (11\%), France (9\%), Poland (6\%), the Czech Republic (6\%), and Belgium (5\%), and the largest importer of plastic parts and components, followed by France and the United Kingdom (Centre for the Promotion of Imports Netherlands, 2016). On the other hand, Italy, France, Poland, and the Netherlands are the main importers of German plastics (Germany Trade and Invest, 2017).

As a whole, plastic consumption within Europe has also shown a steady increase, estimated at 46.3 million tonnes in 2013 and 49 million tonnes in 2015 per year (Frölich, 2014; PlasticsEurope, 2016). The biggest demand found in following countries: Germany, Italy, France, Spain, United Kingdom and Poland. In 2015, the countries consumed 24.6\%, 14.3\%, 9.6\%, 7.7\%, 7.5\% and 6.3 $\%$ of the total quantity, respectively (Statista, 2018).

The packaging industry covers the largest share $(40 \%)$ of plastic material demand in the EU (Plastics Europe, 2018). The building and construction sector as well as the automotive sector are the other main markets of plastics, forming respectively $20 \%$ and $10 \%$ of the total plastic demand. The share of electrical and electronic equipment is approximately $6 \%$ and households, leisure and sports is $4 \%$ of the total use of plastics. All other sectors including appliances, mechanical engineering, furniture, medical technology etc., together, comprise approximately $17 \%$ of the share of plastics consumed in Europe (Plastics Europe, 2018).

The recycling of plastics is necessary in order to minimise the pressure on additional natural resources (Dahlbo et al., 2018). The management of plastic waste is largely determined by the type of plastic materials (Urreaga et.al., 2015). Although plastic waste management is improving in the EU, a relatively large share of plastic waste is still sent to landfill in many countries (the EU average being $27 \%$ ). The majority ( $41 \%$ ) of plastic waste in the EU is sent to incineration, mainly as part of mixed municipal waste. Approximately $30 \%$ of plastic waste is recycled (PlasticsEurope, 2018). Plastic materials can be recycled in a variety of ways and the ease of recycling varies according to polymer type, product design and type (see Table 1). For example, rigid packaging containers consisting of a single polymer are simpler and more economically feasible to recycle than multi-layer and multi-component packages or products of miscellaneous plastic. The variety of plastic materials and types makes the recycling of end-of-life plastics difficult. The level of recycling of different plastic products also depends whether the product falls under the producer responsibility or other collection/recycling obligation. The overall recycling rate of plastic waste is still low, comparing with other materials such as paper, glass or metals. 
2 Table 1. An overview of main types of plastic and their collection/recycling levels

3

\begin{tabular}{|c|c|c|c|}
\hline Plastic type & $\begin{array}{l}\text { Main product } \\
\text { categories }\end{array}$ & Recyclability & $\begin{array}{l}\text { Level of collection and } \\
\text { recycling }\end{array}$ \\
\hline $\begin{array}{l}\text { Polyethylene } \\
\text { Terephthalate (PET) }\end{array}$ & $\begin{array}{l}\text { Packaging material (e.g. } \\
\text { beverage bottles) } \\
\text { Textile applications }\end{array}$ & Easy to recycle & $\begin{array}{l}\text { Packaging: high } \\
\text { Textile applications: low }\end{array}$ \\
\hline $\begin{array}{l}\text { High density } \\
\text { polyethylene (HDPE) }\end{array}$ & $\begin{array}{l}\text { Packaging materials (e.g. } \\
\text { milk, detergent and oil } \\
\text { containers) } \\
\text { Construction materials } \\
\text { (e.g. pipes) }\end{array}$ & Easy to recycle & $\begin{array}{l}\text { Packaging: moderate } \\
\text { Other products: low }\end{array}$ \\
\hline $\begin{array}{l}\text { Polyvinyl chloride } \\
\text { (PVC) }\end{array}$ & $\begin{array}{l}\text { Packaging material } \\
\text { (vegetable oil bottles, } \\
\text { food wrap) } \\
\text { Construction materials } \\
\text { (flooring material, } \\
\text { window frames) }\end{array}$ & $\begin{array}{l}\text { Difficult to } \\
\text { recycle }\end{array}$ & $\begin{array}{l}\text { Packaging: low } \\
\text { Other products: low }\end{array}$ \\
\hline $\begin{array}{l}\text { Low density } \\
\text { polyethylene (LDPE) }\end{array}$ & $\begin{array}{l}\text { Packaging material (e.g. } \\
\text { plastic bags and film) }\end{array}$ & $\begin{array}{l}\text { Easy to recycle } \\
\text { (most recycled } \\
\text { type of plastic) }\end{array}$ & Packaging: high \\
\hline Polypropylene (PP) & $\begin{array}{l}\text { Packaging material (e.g } \\
\text { food and other } \\
\text { containers, PP-cups, } \\
\text { straws, bottle caps) } \\
\text { Automotive industry } \\
\text { plastic parts }\end{array}$ & Easy to recycle & $\begin{array}{l}\text { Packaging: moderate } \\
\text { Other products: low }\end{array}$ \\
\hline Polystyrene (PS/EPS) & $\begin{array}{l}\text { Packaging material (e.g. } \\
\text { food containers, trays, } \\
\text { cups and protection } \\
\text { packaging) } \\
\text { Construction material } \\
\text { (e.g. insulation material) }\end{array}$ & $\begin{array}{l}\text { Difficult to } \\
\text { recycle }\end{array}$ & $\begin{array}{l}\text { Packaging: low } \\
\text { Other products: low }\end{array}$ \\
\hline Miscellaneous plastics & $\begin{array}{l}\text { Different products } \\
\text { (sunglasses, computer } \\
\text { casing, nylon, compact } \\
\text { discs, baby bottles, etc) }\end{array}$ & $\begin{array}{l}\text { Difficult to } \\
\text { recycle }\end{array}$ & $\begin{array}{l}\text { Collection: high } \\
\text { Recyclability: Very low }\end{array}$ \\
\hline
\end{tabular}

4

Table 1 tries to illustrate the diversity of plastic available on the market today, and the different levels of recyclability they have. It can be seen that, in most cases, the plastic modalities which are characterized by a greater recyclability have high levels of collection, whereas those which are difficult to recycle- such as miscellaneous plastics- have low levels of recyclability, despite high collection rates. The reasons for them are twofold: the wide availability of these materials and the comparatively low costs in producing them, a factor which serves to discourage their recycling. A trend seen in many plastic products.

Whereas the recycling of some types of wastes such as food waste is a common feature today (Leal Filho, Kovaleva 2014), the potential for recycling plastic waste in the EU remains largely untapped. It is worth mentioning that not all plastic waste collected for recycling is recycled inside the EU. Europe is the major exporter of waste plastic intended for recycling (Velis, 2014). The exported amount is about $37 \%$ of the overall plastic for recycling (PlasticsEurope, 2018), 87\% of which has been absorbed by China (Velis, 2014). The recent decision by China, who has been the world's largest importer of plastic waste, to ban the import of 24 types of waste types (including specific types of plastic waste), has created a serious problem for the recycling of European plastic waste. 
The low demand of recycled plastics, low commodity prices and uncertainties about market outlets has hindered the development of EU plastic recycling sector. Investments in plastic recycling have been suspended and the recycling sector remains underdeveloped and fragmented (Milios et al 2018). However, plastics can make a major contribution towards a circular economy, helping to achieve a more resource-efficient and circular European recycling industry. Therefore, there is an urgent need to increase the efforts of the recycling of plastic waste in Europe.

There is a high possibility that plastic waste is released to environment if it is not properly collected and treated. As a result, it can cause dangerous impacts in the marine environment (Jahnke et. al 2017; Koelmans et. al., 2014; Lamb et. al., 2018; Lasut et. al., 2018), freshwater ecosystems (Besseling et al., 2017; Blettler et al., 2018; Rodrigues et al.,2018), the soil (Bläsing \& Amelung, 2018; Chae \& An, 2018; Scheurer \& Bigalke, 2018; Zubris \& Richards, 2005) and the food chain (Lusher, Hollman \& Mendoza-Hill, 2017; Romeo et. al., 2015).

One of the notable challenges in the plastic waste management is that it is discharged into the marine environment (Law, 2017; Walker, 2018). This occurs not only through direct pollution by beach and sea littering, but also with a numerous other ways like freshwater ecosystems and atmospheric transport, as well as fishing and shipping activities (Walker et. al, 1997). The landbased sources, as opposed to marine-based sources, are considered the dominant input of plastics into oceans (GESAMP, 2016). Every year 5-15 $\mathrm{mt}$ of plastic is discharged into oceans, therefore the age we live in is named "plasticene" (Ten et. al, 2018). Over time, plastic waste that reached to the seas and oceans are degraded into fragments (macro and micro plastic). This specific type of pollutants rapidly spreads in the water, widely affecting marine environment (including several hundreds of marine species) (Wright et at, 2013; GESAMP, 2016).

Plastic waste in the marine environment is not only killing flora and fauna, but also endangering health of the human population by threatening the food security. For instance it was investigated the high frequency of plastic fragments in the bluefin tuna (Gall \& Thompson 2015; Romeo et. al., 2015). According to these results, PBT compounds (PAH, PCB, PBDE, DDT) and plastic additives can cause alteration on the reproductive system and endocrine disruptors. Moreover, concentration of plastic debris in top predator's fish body is increasing not only by direct particles consumption, but also with a species from successively lower levels in a food chain. The conclusion that can be drawn from these findings are that humans who have in the diet large pelagic fish containing microplastics could also have a health problem, although it is not explicitly stated (Romeo et. al., 2015).

\section{Extended Producer Responsibility as a cornerstone for circular plastics economy}

The EU has recently focused more attention to transform Europe to more circular and resource efficient economy. The EU Action Plan for a circular economy, adopted in December 2015, identified recycling and reuse of plastics as a key priority. The recently adopted European Strategy for Plastic in a Circular Economy aims to increase significantly the prevention and recycling of plastics including the target to make all plastic packaging on the EU market recyclable by 2030 and to reduce the consumption of single-use plastics (European Commission, 2018). The EU strategy seeks to address the planned targets throughout the plastics supply chain, from the design of products through production and usage to the end-of-life stage, through stimulating the EU recycling capacity and internal market for recycled plastic and adopting different fiscal and legislative measures. The phasing out of single-use plastics is also targeted outside of Europe as a result of increasing governmental and public attention to the issue (Xanthos \& Walker, 2017).

Extended Producer Responsibility (EPR) is considered to be one of the major waste management policy instruments that support the implementation of the European waste hierarchy (Milios et at 2018). It has been a main policy instrument in EU that has contributed to the collection and recycling of waste streams that contain plastic. It is also recognised, that EPR can significantly 
1 help to contribute to achieving existing EU waste targets, and the new more ambitious targets in

2 the EU Circular Economy Package (Watkins et al, 2017).

3 EPR is defined as an environmental policy principle in which a producer's responsibility is 4 extended to the post-consumer stage of a product's life including take-back, recycling and final 5 disposal (Lindhqvist, 2000; OECD, 2014). It is based on the knowledge that producers are best 6 positioned actors to make the required changes (e.g. collection and recycling) to minimize impacts 7 of their products. . The type of responsibility varies between producer responsible organizations 8 (PROs). The most commonly PROs take financial and organizational obligations. The simple 9 financial responsibility include usage of fees from producers to set up and manage a take back system such as Belgian scheme for industrial packaging or UK system of electronic Packaging Waste Recovery Notes (ePRNs) (Watkins et al, 2017). Another possibility to go through direct reimbursement contracts with municipalities as done in Czech Republic, Denmark and France (European Commission, 2014c). Organizational responsibilities include full or partial involvement. In terms of full organizational responsibility, the PRO is responsible for the organization of the collection and recycling of packaging waste as in Austria and Denmark. In partial responsibility, usually municipalities are responsible for collection and sorting of waste and PRO reimburses them and sells for example sorted material as in Belgium for household packaging waste (European Commission, 2014c).

„It should be pointed out that EPR is a policy approach under which producers are given a significant responsibility - financial and/or physical - for the treatment or disposal of postconsumer products. It should not be confused with an act.

The applications of EPR principles are manifold -also out of the plastics industry- and that because it is so, it cannot fully meet the specific requirements for all categories of plastic. Indeed, EPR principles also aim at internalising environmental externalities and providing an incentive for producers to take into account environmental impacts throughout a product's life cycle, from material excavation and supply to their end-of-life stage (OECD, 2016). In this way, EPR provides a basis for effective end-of-life collection, improved reuse and recycling of collected products and driving manufacturers to safe resources making products with a lower environmental impact. (OECD, 2014). The experiences with EPR programmes in different EU countries have shown that the concept can be a key instrument and one of the basis moving towards a Circular Economy (Liu et al., 2018; Walker \& Xanthos, 2018; Zero Waste Europe, 2017; European Commission, 2018).“

EPR was first implemented in Europe in the early 1990s for beverage packaging (Lindhqvist, 2000). Since then the EPR strategies have been applied through the EU legal framework to several other products such as electrical and electronic equipment (EEE), batteries and end-of-life vehicles. Today, most of the EU Member States have introduced EPR schemes for packaging waste collection and recovery. Implementation of EPR schemes differs between countries including mandatory regulations, voluntary agreements as well as voluntary industry initiatives.. The EPR is implemented through different range of instruments, such as regulatory take-back schemes and recycling requirements or DRS for beverage containers (BIO, 2014).

EPR for packaging has contributed to significant increases in recycling rates in the EU (OECD, 2016). This applies also to plastic packaging where recycling reached in average $40 \%$ in 2015 , which is well above the requested $22.5 \%$ of the EU Packaging and Packaging Waste Directive. Since the plastic consists largely of fossil fuels, the energy recovery and incineration of plastic packaging waste in the EU has also increased. EU has introduced EPR through several other specific waste legislation such as the ELV Directive 2000/53/EC and WEEE Directive 2012/19/EU(EC, 2014b). Plastic waste stream from end-of life vehicle forms about $12-15 \%$ per 
1 modern average car (Plastics Europe, 2013). According to European Commission (2007), the 2 average plastic content in WEEE is about $30 \%$. Recycling of such plastic is quite problematic as 3 far as it contains some hazardous parts such as heavy metals and brominated flame-retardants.

4 In addition, several member states have adopted their own national or regional legislation that 5 introduces collection and recycling of waste streams that contain plastic. For example, Ireland has 6 established EPR schemes for WEEE, end of life vehicles, batteries, packaging, agricultural 7 plastics, tyres and have plans to implement EPR for textile waste (textile waste also contains today 8 a significant amount of polymers/plastic). However, France, has already adopted EPR scheme for 9 textile waste, establishing obligation for producers to take back $50 \%$ of the volumes put on the 10 market. Similarly, Sweden assessed the possibility for implementation of mandatory EPR system 11 for textile products, however, final decision has been left to PROs.

12 Several Member States adopted EPR scheme for agricultural plastic waste (Table 2). Agri-plastics 13 cover wide range of plastics used in agriculture such as plastic mulch films, row coverings, high 14 and low tunnels, greenhouses (ApeEurope, 2018). The collection rate of agri-plastics waste for 15 these countries is between 75\% and 95\%, with high recycling of 98\% (Ape Europe 2018). In some 16 countries, EPR has been implemented for other specific types of waste containing plastic such as 17 disposable plastic kitchenware (Belgium); pesticide, fertilizer, seed and plant packaging, furniture, 18 office equipment and ink cartridges (France); medical and pharmaceutical packaging (Portugal); 19 plastic foils and bulky plastics (Austria) (European Commission, 2014).

20 Table 2 presents an overview of EPR schemes implemented for different types of plastic waste in 21 EU Member States. 
1 Table 2. An Overview of EPR schemes adopted for plastic related waste streams in the EU 28

2

\begin{tabular}{|c|c|c|c|c|c|}
\hline Country & Packaging & WEEE & ELV & $\begin{array}{l}\text { Agricultural } \\
\text { plastic }\end{array}$ & Other \\
\hline Austria & $\sqrt{ }$ & $\sqrt{ }$ & $\sqrt{ }$ & & Plastic foils and bulky plast \\
\hline Belgium & $\sqrt{ }$ & $\sqrt{ }$ & $\sqrt{ }$ & $\sqrt{ }$ & $\begin{array}{l}\text { Disposable plastic } \\
\text { kitchenware }\end{array}$ \\
\hline Bulgaria & $\sqrt{ }$ & $\sqrt{ }$ & $\sqrt{ }$ & & \\
\hline Croatia & $\sqrt{ }$ & $\sqrt{ }$ & $\sqrt{ }$ & & \\
\hline Cyprus & $\sqrt{ }$ & $\sqrt{ }$ & $\sqrt{ }$ & & \\
\hline Czech Republic & $\sqrt{ }$ & $\sqrt{ }$ & $\sqrt{ }$ & & \\
\hline Denmark & $\rho$ & $\sqrt{ }$ & $\sqrt{ }$ & & \\
\hline Estonia & $\sqrt{ }$ & $\sqrt{ }$ & $t b$ & & \\
\hline Finland & $\sqrt{ }$ & $\sqrt{ }$ & $\sqrt{ }$ & $\sqrt{ }$ & \\
\hline France & $\sqrt{ }$ & $\sqrt{ }$ & $\sqrt{ }$ & $\sqrt{ }$ & $\begin{array}{l}\text { Textile, pesticide, fertilizer, } \\
\text { seed and plant packaging, } \\
\text { furniture and office } \\
\text { equipment, ink cartridges }\end{array}$ \\
\hline Germany & $\sqrt{ }$ & $\sqrt{ }$ & $t b$ & $\sqrt{ }$ & \\
\hline Greece & $\sqrt{ }$ & $\sqrt{ }$ & $\sqrt{ }$ & & \\
\hline Hungary & $\sqrt{ }$ & $\sqrt{ }$ & $\sqrt{ }$ & & \\
\hline Ireland & $\sqrt{ }$ & $\sqrt{ }$ & $\sqrt{ }$ & $\sqrt{ }$ & \\
\hline Italy & $\sqrt{ }$ & $\sqrt{ }$ & $\sqrt{ }$ & $\sqrt{ }$ & \\
\hline Latvia & $\sqrt{ }$ & $\sqrt{ }$ & $\sqrt{ }$ & & \\
\hline Lithuania & $\sqrt{ }$ & $\sqrt{ }$ & $\sqrt{ }$ & & \\
\hline Luxemburg & $\sqrt{ }$ & $\sqrt{ }$ & $\sqrt{ }$ & & \\
\hline Malta & $\sqrt{ }$ & $\sqrt{ }$ & $N / A$ & & \\
\hline Netherlands & $\sqrt{ }$ & $\sqrt{ }$ & $\sqrt{ }$ & & Window panes \\
\hline Poland & $\sqrt{ }$ & $\sqrt{ }$ & $\sqrt{ }$ & & \\
\hline Portugal & $\sqrt{ }$ & $\sqrt{ }$ & $\sqrt{ }$ & & $\begin{array}{c}\text { Medical and } \\
\text { pharmaceutical packaging }\end{array}$ \\
\hline Romania & $\sqrt{ }$ & $\sqrt{ }$ & $t b$ & & \\
\hline Slovakia & $\sqrt{ }$ & $\sqrt{ }$ & $\sqrt{ }$ & & \\
\hline Slovenia & $\sqrt{ }$ & $\sqrt{ }$ & $\sqrt{ }$ & & \\
\hline Spain & $\sqrt{ }$ & $\sqrt{ }$ & $\sqrt{ }$ & $\sqrt{ }$ & \\
\hline Sweden & $\sqrt{ }$ & $\sqrt{ }$ & $\sqrt{ }$ & $\sqrt{ }$ & \\
\hline United Kingdom & $\sqrt{ }$ & $\sqrt{ }$ & $\sqrt{ }$ & & \\
\hline
\end{tabular}

$\sqrt{ }$ - EPR scheme; tb - takeback obligation, no PRO; $\rho$ - product fee

obligation/governmental fund. Source: European Commission, 2014

3 


\section{Opportunities for more ambitious EPR}

Despite some success, the EPR implementation for plastics containing waste streams in the EU has shown several problems and weaknesses (OECD, 2014; Zero Waste Europe, 2015; Watkins et al, 2017). The implementation of EPR lacks harmonisation and transparency across the EU; it differs in scope and goals, as well as performance and costs, in different Member States. This is mainly due to the lack of harmonised EU-wide approach to EPR that has led to very different implementation schemes, procedures, fee levels, product coverage and other aspects across the EU Member States. Therefore, the EPR framework needs to be redesigned and this should also include the move towards the reduction of plastic waste, to ensure the transition to a sustainable Circular Economy (Watkins et al, 2017; European Commission, 2018).

There are many possibilities and new approaches to make the existing EPR schemes for plastic packaging and other post-consumer plastic waste streams more efficient and effective. The EU Plastic Strategy and several studies that contributed to the development of the Strategy and discussions on EU Circular Economy Package (Zero Waste Europe, 2015; Watkins et al, 2017) have suggested several recommendations in this matter. A short overview of the main actions that could play a significant role in EPR redesign, including more sustainable use of plastic, is described below.

\subsection{Harmonisation of EPR in the EU}

EPR principles set in the EU legislation are flexible and enable different implementation approaches at national level in accordance with the specific conditions of the Member States. Each Member State may set different rules for their EPR schemes. At the same time, the definition of EPR is not clear enough and differs in both goal and scope in the European Union as well as Member States legislation (Watkins et al, 2017). As a result, Member States have taken varying approaches to regulate the EPR schemes: for example, EPR can be implemented either as collective or individual producer responsibility, with full financial responsibility or partial operational responsibility of producer responsibility organisations. The lack of a common basis and approach has led to diverse requirements as well as performances of EPR schemes across the EU. The different collection/recycling fees of PROs often favour certain plastic materials above others and could create problems for producers that act in the different Member States. Therefore, there is need for common definitions and a more harmonised approach for the EU (Watkins et al, 2017). This should include also a harmonisation of other relevant economic instruments (e.g. product or waste taxes). In addition, it is also important to ensure fair competition between EPR schemes on a national as well as EU level and better transparency on performance and costs/fees. 3.2. Extending EPR to other plastic products

The experiences of EPR in plastic packaging waste and to a lesser extent in other products that fall under the common EU EPR obligation (e.g. WEEE, end-of-life vehicles) have shown that it is possible to achieve relatively high separate collection and recycling rates. Therefore, it should be considered to widen the scope of EPR to other plastic products. These products can be such as: pharmaceutical packaging, agricultural plastic, plastic used as construction material, furniture and carpets, printer cartridges. More comprehensively can be investigated some specific waste streams such as bulky metals, glass, plastics and wood, composite packaging (Tetra-Pack) as well as textile waste. Several EU Member States have already successfully applied EPR to the some of the named products (Watkins et al, 2017).

\subsection{The role of circular design}

The proper product design and especially circular design (e.g. design for reuse and recyclability) is one of the key issues to improve reuse and recycling levels of end-of-life products. Without significant redesign, it is not possible to reuse or recycle significant amount (ca $30 \%$ ) of plastic packaging. In addition, design improvements significantly lower (ca 50\%) the cost of recycling plastic packaging waste (Ellen MacArthur Foundation, 2017). The current experiences of EPR implementation in different EU Member States have however shown that the applied measures have not succeeded in motivating packaging producers to turn to eco and circular design (Zero Waste Europe, 2015). The main reasons for this are the relatively low compliance costs (collection 
and recycling) for producers with EPR and the lack of differentiation of producer fees based on circular design (e .g. reusability or recyclability) (Pires et al, 2015; Watkins et al, 2017). PROs use usually weight-based fees that are often averaged across producers. In some countries, collection and recycling costs are only partly covered by producers. This does not motivate innovation in terms of circularity when designing the plastic packaging or other plastic products under EPR.

To ensure improved circular design of plastic products under the EPR, common incentives are important for producers that favour circular products and incorporate EPR as part of their business models, instead of treating it separately. EU-wide criteria for EPR should be harmonised so that they include the minimum requirements on products design regarding the material design and origin of materials (e.g. small or composite packaging) as well as limits for additives/chemical substances that are problematic for product waste management and recycling. The other option is to differentiate or modulate the EPR fees aiming to guide producers towards more responsibility for their products that are launched on the market. (Watkins et al, 2017).

In the case of plastic packaging, the fee structure could, for example, stimulate the use of reusable packaging or recycled and bio-based plastic, reward design for more recyclability as well as costs for packaging that is difficult to recycle, or reuse could be increased. However, the introduction of differentiated fees for plastic products could have certain challenges. In practice, product design is not always implemented by the actors responsible for paying the producer fees. This is especially the case for smaller countries where the share of imported products is high and the possibility to influence the product or packaging design through local EPR legislation is weak. Therefore, a common EU-wide harmonised EPR criteria in this area is important (Deloitte, 2014).

\subsection{Improvement of separate collection and treatment of wastes}

Most of the EPR schemes tend to achieve no more than the collection and recycling targets set in the waste legislation. Future higher recycling targets will require more efficient collection, sorting and final treatment of waste. Various modern and efficient recycling technologies for plastic waste have been developed. However, no matter how efficient the recycling technologies are, the experiences of EPR schemes show that source separation and sorting is the most important step in the recycling loop. Adequate source separation and sorting ensures better quality of recycled plastic material. This also helps to avoid contaminants in the collected waste that create the basis for further use of the recycled materials. Growth and expansion of plastic recycling is therefore often restrained by insufficient volumes and low quality of collected plastic waste.

Several surveys carried out by the European Commission have shown that approximately $90 \%$ of European consumers think that better and more collection facilities for plastic need to be provided (European Commission, 2017). Therefore, in the light of increasing recycling targets, there is a need to improve the separate collection and sorting of the plastic waste under the EPR. Regional and local authorities together with PROs play a key role in developing adequate collection schemes and raising public awareness that is needed to ensure a well-functioning separate collection (European Commission, 2018). It is clear that the focus on low-cost collection solutions, for example, collection of mixed packaging or collection of waste streams that are easy to collect (e.g. bulk commercial plastic packaging), is not enough to increase the recycling of plastics.

\subsection{Extending the deposit refund systems (DRS)}

Increasing recycling targets and littering of plastic packaging have led to the exploration of alternative systems to the existing kerbside collection system. The experiences of several EU countries have shown that mandatory DRS have proved to be highly successful in diminishing littering as well as reaching high levels of collection and recycling (Eunomia, 2011).

46 In comparison with alternative or parallel systems, the benefit of a DRS is the financial motivation.

47 The deposit sum has shown to be an important incentive and lead to substantial return/collection rates. Typically, countries with deposit refund schemes for plastic containers achieve recycling rates of approximately $80-95 \%$ (EAC, 2017). Another positive aspect is that the collected plastic material has a much higher quality compared to the kerbside collection system. This creates higher resource efficiency for collected plastic waste as it can be recycled in much higher volumes and higher level (e.g. bottle-to-bottle recycling). The deposit refund system also creates the basis for 
product reuse systems. For example, the Estonian DRS has ensured a much higher share of reuse and also recycling of beverage containers than in the neighbouring countries of Latvia and Lithuania (Moora and Uselyte, 2011). The well-functioning and cost-effective DSR system has provided economic incentive for Estonian beverage manufacturers to use refillable bottles over the one-way containers and preserve the refillable infrastructure. As a result, the share of refillable beverage bottles is relatively high, especially comparing with one-way PET bottles. The depositbased reuse systems are also increasingly used for transport packaging, such as plastic crates and pallets.

A DRS provides an alternative funding mechanism for the collection and recycling of plastic containers based on the "polluter pays" principle. The experience of the Estonian DRS for beverage containers shows that the costs for producers can be relatively low (Leal et al, 2016). Typically, in a well-functioning DRS, the unredeemed deposit, together with the value of the highquality materials that are collected, are the key sources of funding to the scheme. It should be noted that not all plastic products are appropriate for DRS. Nevertheless, the cost-efficiency of the DSR depends on the administrative set-up and implementation of the scheme. In a well-designed DRS, the on-going financial and environmental benefits usually outweigh the costs of operating a system. Based on the positive effects mentioned above, the wider implementation of the DRS in the EU countries could significantly increase the reuse and recycling of plastic containers and reduce the littering of plastic waste. One option could be the implementation of an EU-wide DRS for one-way beverage packaging (European Parliament, 2011). This would help the producers to optimise production and the logistics of their products, and the free movement of goods would not be restricted. The initiative must come from the governments, but the ability to make manufacturers and retailers work together has a critical role to play when implementing a wellfunctioning deposit refund system.

\subsection{Incorporating EPR in a sustainable and circular business model}

EPR has already been applied in the case of packaging waste with varying license fees in European countries (e.g. Green Dot System for packaging waste) (PRO Europe, 2018). However, the management of packaging waste or packaging design has not yet improved substantially and noticeably from an environmental perspective (Pires et al. 2015). EPR is targeted to enable the transition to the circular economy; however, the role of the business model that the producers are to adopt has not been clarified in this context and thus the producers' business and economic profitability have not been taken into account.

A business model is commonly defined with three main components, the value proposition, the value creation and delivery, and the value capture (Osterwalder and Pigneur, 2005). A sustainable business model (SBM) is based on a triple bottom line approach, that takes into account the economic, environmental and social spheres in the business ecosystem and the different kinds of stakeholders on the three levels (Antikainen and Valkokari, 2016; Bocken et al. 2014). The value proposition in a sustainable business model should provide measurable ecological and social value in addition to the economic value (Boons and Lüdeke-Freund, 2013; Bocken et al., 2014). SBMs necessitate that firms change and develop their organizations and business to enable more transparency and create sustainable value to all of their stakeholders (Aagaard, 2019). The focus in SBMs is on innovation for sustainability, and the business strategy and processes of firms using plastics as a resource should thus develop their business with economic, social and environmental considerations and take into account the full life-cycle of their product and the requirements of the stakeholders in the business ecosystem.

Business models which consider EPR may be helpful when developing the sustainability of a business which produces or relies on plastic. It is known that when firms focus on the circular design and eco-efficiency they can reduce energy, emissions and waste in their production. These developments, however, are not lowering total resource usage and environmental impacts of production as the number of products created is still increasing due to growth of global population and demand (Bocken et al. 2014). Regardless of potential developments in energy efficiency, it 
1 may result in greater production and sales of products produced out of plastic, as they are more 2 affordable, thus creating a rebound effect (Herring and Sorrell, 2009).

3 A circular business model aims at creating value in economically viable ways by reusing products 4 and recycling materials, and using renewable resources whenever possible (Bocken et al., 2016). 5 One way to implement a circular business model is to extend the product value by exploiting the 6 residual product value and aiming at offering consumers affordable products that have been 7 remanufactured, repaired or other ways designed to last longer by design (Bocken et al., 2016). 8 Firms could set up platforms where consumers could benefit from the residual value of their 9 products (e.g. sales of used products on a website). In a circular business model, the aspects of 10 creation and delivery could consist of take-back systems (e.g. collection points at retailers) to value by reducing material costs, and even though there may be some labour and logistics expenses added, the total product costs can decrease by using recycled material. There could also be third parties that make use of other firms' products, however, the producers could already design their products so that they could be reused and remanufactured and thus apply a circular business model (Bakker et al. 2014). In the development of a sustainable business model, firms need to cooperate with stakeholders in the private and public sector to be successful (Stubbs and Cocklin 2008). When sustainable and circular business models are combined, the approach is a sustainable circular business model (SCBM) where the triple bottom line approach is combined with a systems perspective (Antikainen and Valkokari, 2016).

A SCBM holistically views the entire business ecosystem including the trends and stakeholders, analyzes sustainability costs and benefits, and evaluates iterative cycles of sustainability and circularity in the business context. Minimisation of the environmental impact of the end-of-life of products has to be implemented on a systems level. Therefore, the products and production systems of firms need to be designed with circular design principles (Spicer and Johnson, 2004).

Bocken et al. (2014) have classified sustainable business models into eight different archetypes that provide different models facilitating the transition to a circular economy. These include: "1) Maximise material and energy efficiency; 2) Create value from 'waste'; 3) Substitute with renewables and natural processes; 4) Deliver functionality rather than ownership; 5) Adopt a stewardship role; 6) Encourage sufficiency; 7) Re-purpose the business for society/environment; and 8) Develop scale-up solutions". All of these archetypes require demonstrations of EPR as the producer is creating value in novel ways and extending the life and sustainability of the products to some extent.

Based on the above, it can be concluded that EPR could provide clear economic incentives for producers/firms and consumers favouring circular products. It motivates already existing plastic product producers and firms to think about alternative business approaches (e.g. reuse and recycling schemes). The existing producer initiatives and producer responsibility schemes could also help to build bridges with producers, recyclers and reverse logistic systems, initiating in this way also new business possibilities and relationships. The EPR could also provide opportunities for new and innovative circular business models and initiatives (e.g. re-use/deposit, repair and product-service schemes, and sharing platforms). In the case of plastic products, the EPR could stimulate also the circular bio-based economy. Bio-based plastics are already offering true potential in all of the three pillars of sustainability (Spierling et al., 2018; de Vargas Mores et al, 2018). The new development of sustainable and biodegradable materials, such as lignocellulose, offers firms viable ways to replace petroleum-based plastics in their production and packing materials. For example, molded pulp products and bio-based foams can be used as packaging materials and advanced cellulose films and paper can be utilized as barriers for oxygen, carbon dioxide gases and water vapor ( $\mathrm{Su}$ et al., 2018). When companies invest in replacing petroleumbased plastics in their production and packaging, they are laying the foundations for their SBMs. Thus, they will also have the possibility to avoid the financial costs related to the handling of petroleum-based plastic waste in their business and, at the same time, they are supporting society in the transition towards a more sustainable and bio-based circular economy. 
1 As it was mentioned in the previous sections, the harmonization of scope, definition and

\section{Conclusions}

As this paper has shown, plastic is a valuable material on the one hand, but a problematic waste on the other, associated with health and environmental impacts. The problems seen in the current use, and the expected growth in the deployment of plastic in a wide range of areas in the future, suggest that an efficient recycling plan is urgently needed, in order to minimise the pressure it currently puts on the natural environment, both during its production and its disposal. Yet, except for a few, isolated attempts, the potential for recycling plastic waste remains largely untapped Despite the overall negative trends, plastics can make a major contribution towards a circular economy. This paper has shown that Extended Producer Responsibility may be one of the ways via which things can move forward. EPR can significantly help to contribute to achieving existing EU waste targets, and the new ambitious targets in the EU Circular Economy Package.

The EPR implementation for plastic-containing waste streams in the EU has shown several problems and weaknesses, which vary from the lack of binding mechanisms, to lack of incentives for enterprises to fully engage. Therefore, the EPR framework needs to be redesigned, and this should also include concrete measures which may lead to a reduction of plastic waste.

But apart from plastic per se, a wider application of EPR to other products is possible (and needed). As the experiences from several EU Member States have shown, it is possible to extend the EPR based schemes also to other waste streams containing plastic (e.g agricultural plastics, textile waste, plastic used in construction, medical and pharmaceutical packaging, bulky plastics, furniture, printer cartridges, textile and carpets, etc). Yet, so far, the main focus has been on packaging. Other products should also be included in the framework of EPR.

The implications of the paper are threefold. Firstly, it shows the differences across the EU. Secondly, it demonstrates why a greater harmonisation of EPR approaches is needed. These should consider, for instance, the compatibility of other relevant economic instruments to steer plastic demand and use in the right direction (e.g. product or waste taxes). Finally, the paper illustrates the need to ensure a fair competition between EPR schemes on a national as well as EU level, and better transparency on performance and costs/fees.

Based on the positive experiences of EU Member States it is recommended that a wider implementation EU-wide DRS for one-way beverage packaging takes place. This would help producers to optimise production and the logistics of their products, and the free movement of goods would not be restricted. It is also necessary to take into account the fact that even though such initiatives need to be taken by governments, the views and perspectives of manufacturers, fillers, packers and retailers need to be taken into account when implementing schemes such as a deposit refund system. Also, consumers need to engage further and steer more demand for biological based plastic materials, which are biodegradable.

Future higher plastic recycling targets will also require more efficient collection, sorting and final treatment of plastic wastes. In the light of increasing recycling targets, there is a need to improve 
1 the separate collection and sorting of the plastic waste under the EPR. Regional and local authorities, in cooperation with PROs, have a key role to play in developing the adequate collection schemes and raising public awareness that is needed to ensure a high-quality separate collection. Financial resources collected through the EPR schemes can do much to amplify such efforts. It is clear that the focus on low-cost collection solutions, for example, collection of mixed packaging or collection of only lowest cost waste streams, is not enough to increase the recycling of plastics. In order to yield the expected benefits, EPR should be seen as a part of a wider policy mix. Coherence should for instance be ensured between the objectives and implementation of EPR and other regulatory and economic instruments such as recycling targets, bans, product/material and waste taxes, pay-as-you-throw schemes, labelling, voluntary agreements, procurement policies, and information and awareness campaigns.

A more ambitious and harmonised plastic-based EPR implementation plan in EU Member States may significantly contribute towards higher a circular economy in the plastics sector, hence helping to reduce a problem which bears a direct influence to environmental quality and human well-being, both in Europe and elsewhere.

\section{References}

Aagaard, A. 2019. Identifying Sustainable Business Models Through Sustainable Value Creation. In Sustainable Business Models (pp. 1-19). Palgrave Macmillan, Cham.

Antikainen M., and Valkokari, K., 2016. A Framework for Sustainable Circular Business Model Innovation. Technology Innovation Management Review, 6:7.

ApeEurope, 2018. European Regulation-National collecting Schemes (NCS). Available at: http://www.plastiques-agricoles.com/ape-europe-missions/agricultural-plastics-europeanregulation//Accessed: 23.05.2018

Bakker, C., M. Den Hollander, E. van Hinte and Y. Zijlstra., 2014. Product that Last. Product Design for Circular Business Models, TU Delft Library, Delft.

Besseling, E., Quik, J. T. K., Sun, M. \& Koelmans, A. A., 2017. Fate of nano- and microplastic in freshwater systems: A modeling study. Environ. Pollut. 220, 540-548.

BIO Intelligence Service, 2011. Plastic waste in the environment. European Commission (DG Environment). Available at: http://ec.europa.eu/environment/waste/studies/pdf/plastics.pdf

BIO Intelligence Service, 2014. Development of Guidance on Extended Producer Responsibility. Final Report. European Commission.

Bläsing, M., \& Amelung, W., 2018. Plastics in soil: Analytical methods and possible sources. Science of the Total Environment, 612, 422-435.

Blettler, M. C., Abrial, E., Khan, F. R., Sivri, N., \& Espinola, L. A., 2018. Freshwater plastic pollution: Recognizing research biases and identifying knowledge gaps. Water Research, 143, 416-424.

Bocken, N. M., de Pauw, I., Bakker, C., \& van der Grinten, B., 2016. Product design and business model strategies for a circular economy. Journal of Industrial and Production Engineering, 33(5), 308-320.

Bocken, N. M., Short, S. W., Rana, P., \& Evans, S., 2014. A literature and practice review to develop sustainable business model archetypes. Journal of cleaner production, 65, 42-56.

Boons, F., Lüdeke-Freund, F., 2013. Business models for sustainable innovation: state-of- the-art and steps towards a research agenda. J. Clean. Prod. 45, 9-19.

Bourguignon, D., 2017. Plastics in a circular economy: Opportunities and challenges. EPRS | European Parliamentary Research Service, Brussels, 8 p.

Centre for the Promotion of Imports Netherlands, 2016. Exporting plastic parts and components to Europe. Netherlands Ministry of Foreign Affairs. Available at: https://www.cbi.eu/node/2652/pdf/

Chae, Y., \& An, Y. J., 2018. Current research trends on plastic pollution and ecological impacts on the soil ecosystem: A review. Environmental Pollution, 240, 387-395. 
Dahlbo, H., Poliakova, V., Mylläri, V., Sahimaa, O., Anderson, R., 2018. Recycling potential of post-consumer plastic packaging waste in Finland. Waste Management, 71, pp. 52-61. Available at: https://doi.org/10.1016/j.wasman.2017.10.033

Deloitte, 2014. Development of Guidance on Extended Producer Responsibility (EPR). Final report, Paris.

de Vargas Mores, G., Finocchio, C. P. S., Barichello, R., \& Pedrozo, E. A., 2018. Sustainability and innovation in the Brazilian supply chain of green plastic. Journal of Cleaner Production, 177, 12-18.

Available at: https://doi.org/10.1016/j.jclepro.2017.12.138

EAC, 2017. Plastic bottles: Turning Back the Plastic Tide. The House of Commons Environmental Audit Committee, UK. https://publications.parliament.uk/pa/cm201719/cmselect/cmenvaud/339/339.pdf

Ellen MacArthur Foundation, 2017. The New Plastics Economy: Catalysing Action. January 2017. $\begin{array}{lll}\text { World } & \text { Economic } & \text { Forum, }\end{array}$ http://www3.weforum.org/docs/WEF_NEWPLASTICSECONOMY_2017.pdf

Eunomia, 2011. Options and Feasibility of a European Refund System for Metal Beverage Cans. http://ec.europa.eu/environment/waste/packaging/cans/map.htm

European Commission, 2000. COMMISSION DECISION of 3 May 2000 replacing Decision 94/3/EC establishing a list of wastes pursuant to Article 1(a) of Council Directive 75/442/EEC on waste and Council Decision 94/904/EC establishing a list of hazardous waste pursuant to Article 1(4) of Council Directive 91/689/EEC on hazardous waste (2000/532/EC).

European Commission, 2007. Plastics Composition of WEEE and Implications for Recovery. Available at: http://ec.europa.eu/environment/integration/research/newsalert/pdf/63na4 en.pdf [Accessed May 22, 2018].

European Commission, 2014a. New proposals to reduce plastic bag use. Available at: https://ec.europa.eu/environment/efe/themes/waste/new-proposals-reduce-plastic-baguse_en [Accessed February 17, 2018].

European Commission, 2014b. Proposal for a Directive of the European Parliament and of the Council amending Directives 2008/98/EC on waste, 94/62/EC on packaging and packaging waste, 1999/31/EC on the landfill of waste, 2000/53/EC on end-of-life vehicles, 2006/66/EC on batteries and accumulators and waste batteries and accumulators, and 2012/19/EU on waste electrical and electronic equipment, COM (2014) 397 final. Available at: http://ec.europa.eu/environment/waste/pdf/Legal\%20proposal\%20review\%20targets.pdf

European Commission, 2014c. Development of guidance on Extended Producer Responsibility (EPR). Final Report. Available at: http://ec.europa.eu/environment/waste/pdf/target_review/Guidance\%20on\%20EPR\%20\%20Final\%20Report.pdf. Accessed:23.05.2018

European Commission, 2015. Closing the loop - An EU Action Plan for the Circular Economy. Brussels, 2.12.2015 COM (2015) 614 final. Available at: https://eurlex.europa.eu/resource.html?uri=cellar:8a8ef5e8-99a0-11e5-b3b701aa75ed71a1.0012.02/DOC 1\&format=PDF [Accessed July 30, 2018].

European Commission, 2015. Study to develop a guidance document on the definition and classification of hazardous waste. Reference: 07.0201/2014/SI2.697025/EU/ENV.A.2 . FINAL REPORT, BiPRO GmbH, Munich, Germany,160 p.

European Commission, 2017a. Capacity building, programmatic development and communication in the field of environmental taxation and budgetary reform: Final Report, Brussels, Belgium,168p.

European Commission, 2017b. Attitudes of European citizens towards the environment. Special Eurobarometer 468 - Wave EB88.1 - TNS opinion \& social. 2017. http://ec.europa.eu/commfrontoffice/publicopinion/index.cfm/Archive/index 
European Commission, 2018. A European Strategy for Plastics in a Circular Economy. Brussels, 16.1.2018 COM(2018) 28 final. Available at: https://ec.europa.eu/commission/news/firstever-europe-wide-strategy-plastics-2018-jan-16_en [Accessed February 17, 2018].

European Parliament, 2011. A European Refunding Scheme for Drinks containers. Briefing paper, 40 p. http://www.europarl.europa.eu/RegData/etudes/note/join/2011/457065/IPOLAFET_NT(2011)457065_EN.pdf. Accessed 19.02.2018.

European Parliament, 2015. Directive (EU) 2015/720 of the European Parliament and of the Council of 29 April 2015 amending Directive 94/62/EC as regards reducing the consumption of lightweight plastic carrier bags. Available at: https://publications.europa.eu/en/publicationdetail//publication/58d93aee-f3bc-11e4-a3bf-01aa75ed71a1/language-en

European Resource Efficiency Platform, 2014. Manifesto \& Policy Recommendations 31 March, 2014. http://ec.europa.eu/environment/resource_efficiency/documents/erep_manifesto_and_policy recommendations_31-03-2014.pdf

Frölich, J., 2014. A European Plastics Market and Trend Study. Life Cycle Analyses from virgin material until post-consumer waste scenarios. EcoSphere. Available at: http://ptfplus.com/onewebmedia/A\%20European\%20Plastics\%20Market\%20and\%20Trend \%20Study.pdf

Gall, S. C., \& Thompson, R. C., 2015. The impact of debris on marine life. Marine pollution bulletin, 92(1-2), 170-179.

Germany Trade and Invest, 2017. The Plastics industry in Germany. Germany. Available at: https://www.gtai.de/GTAI/Content/EN/Invest/_SharedDocs/Downloads/GTAI/Industryoverviews/industry-overview-plastics-industry-in-germany-en.pdf? $v=12$

GESAMP, 2016. Sources, Fate and Effects of Microplastics in the Marine Environment - Part Two of a Global Assessment. IMO/FAO/UNESCOIOC/UNIDO/WO/IAEA/UN/UNEP/UNDP Jt. Gr. Expert. Sci. Asp. Mar. Environ. Prot. (ed. P. J. Kershaw C. M. Rochman) 220, Study report, London.

Gu, F., Guo, J., Zhang, W., Summers, P.A., Hall, P., 2017. From waste plastics to industrial raw materials: A life cycle assessment of mechanical plastic recycling practice based on a realworld case study. Science of the Total Environment, 601-602, pp. 1192-1207. Available at: http://dx.doi.org/10.1016/j.scitotenv.2017.05.278

Herring, H., Sorrell, S., 2009. Energy Efficiency and Sustainable Consumption: the Rebound Effect. Palgrave Macmillan, Basingstoke.

Jahnke, A., Arp, H. P. H., Escher, B. I., Gewert, B., Gorokhova, E., Kühnel, D., ... \& Toorman, E., 2017. Reducing uncertainty and confronting ignorance about the possible impacts of weathering plastic in the marine environment. Environmental Science \& Technology Letters, 4(3), 85-90.

Koelmans, A. A., Gouin, T., Thompson, R., Wallace, N. \& Arthur, C., 2014. Plastics in the marine environment. Environ. Toxicol. Chem. 33, 5-10.

Lamb, J. B., Willis, B. L., Fiorenza, E. A., Couch, C. S., Howard, R., Rader, D. N., ... \& Harvell, C. D., 2018. Plastic waste associated with disease on coral reefs. Science, 359(6374), 460462.

Lasut, M. T., Weber, M., Pangalila, F., Rumampuk, N. D., Rimper, J. R., Warouw, V., ... \& Lott, C., 2018. From Coral Triangle to Trash Triangle-How the Hot spot of Global Marine Biodiversity Is Threatened by Plastic Waste. In Proceedings of the International Conference on Microplastic Pollution in the Mediterranean Sea (pp. 107-113). Springer, Cham.

Law, K. L., 2017. Plastics in the marine environment. Annual review of marine science, 9, 205229.

Leal Filho, W., Kovaleva, M., 2014. Food Waste and Sustainable Food Waste Management in the Baltic Sea Region. Springer, Berlin. 
Leal Filho, W.L., Brandli, L., Moora, H., Kruopienè, J., Stenmarck, Å., 2016. Benchmarking approaches and methods in the field of urban waste management. Journal of Cleaner Production, 112, 5, 4377-4386.

Lindhqvist, T., 2000. Extended Producer Responsibility in Cleaner Production: Policy Principle to Promote Environmental Improvements of Product Systems, PhD, The International Institute for Industrial Environmental Economics, Lund University.

Liu, Z., Adams, M., \& Walker, T. R., 2018. Are exports of recyclables from developed to developing countries waste pollution transfer or part of the global circular economy? Resources, Conservation and Recycling, 136, 22-23.

Lusher, A., Hollman, P., \& Mendoza-Hill, J., 2017. Microplastics in fisheries and aquaculture: status of knowledge on their occurrence and implications for aquatic organisms and food safety. FAO Fisheries and Aquaculture Technical Paper, (615).

Milios, L., Christiansen, L., Rasch, M., K., Eriksen, M., 2018. Plastic recycling in the Nordics: A value chain market analysis.Journal of Waste Management. Article in press.

Moora, H., Uselytè, R., 2013. Development of municipal solid waste management systems in Estonia and Lithuania. Conference Proceedings. Sardinia 2011, Thirteenth International Waste Management and Landfill Symposium.

OECD, 2014. The State of Play on Extended Producer Responsibility (EPR): Opportunities and Challenges. OECD, Paris.

Osterwalder, A., Pigneur, Y., Bernarda, G. \& Smith, A., 2005. Value proposition de-sign: How to create products and services customers want, John Wiley \& Sons.

Palm, E., Nilsson, L. J., \& Åhman, M.,2016. Electricity-based plastics and their potential demand for electricity and carbon dioxide. Journal of cleaner production, 129, 548-555.

Pires, A., Martinho, G., Ribeiro, R., Mota, M., \& Teixeira, L., 2015. Extended producer responsibility: a differential fee model for promoting sustainable packaging. Journal of Cleaner Production, 108, 343-353.

Plastics Europe, 2013. Automotive The word moves with plastics. https://www.plasticseurope.org/en/resources/publications/104-automotive-world-movesplastics-brochure . Accessed: 22.05.2018

Plastics Europe, 2016. Plastics - the Facts 2016 An analysis of European plastics production, demand and waste data. Brussels, Belgium. Available at: http://www.plasticseurope.org/application/files/4315/1310/4805/plastic-the-fact-2016.pdf

Plastics Europe, 2018. Plastics - the Facts 2017. An analysis of European plastics production, demand and waste data. Brussels, Belgium. Available at: http://www.plasticseurope.org/application/files/5715/1717/4180/Plastics_the_facts_2017_FI NAL_for_website_one_page.pdf

PRO (Packaging Recovery Organisation) Europe, 2018. Overview. http://www.pro-e.org/ (accesed 16.03.2018).

Rodrigues, M. O., Abrantes, N., Gonçalves, F. J. M., Nogueira, H., Marques, J. C., \& Gonçalves, A. M. M., 2018. Spatial and temporal distribution of microplastics in water and sediments of a freshwater system (Antuã River, Portugal). Science of The Total Environment, 633, 15491559.

Romeo, T., Pietro, B., Pedà, C., Consoli, P., Andaloro, F., \& Fossi, M. C., 2015. First evidence of presence of plastic debris in stomach of large pelagic fish in the Mediterranean Sea. Mar. Pollut. Bull. 95, 358-361.

Scheurer, M., \& Bigalke, M., 2018. Microplastics in Swiss floodplain soils. Environmental science \& technology, 52(6), 3591-3598.

Spicer, A. J., \& Johnson, M. R., 2004. Third-party demanufacturing as a solution for extended producer responsibility. Journal of Cleaner Production, 12(1), 37-45.

Spierling, S., Knüpffer, E., Behnsen, H., Mudersbach, M., Krieg, H., Springer, S., ... \& Endres, H. J. (2018). Bio-based plastics-A review of environmental, social and economic impact assessments. Journal of Cleaner Production, 185, 476-491. 
Statista, 2018. Ranking of the leading countries of plastics consumption in Europe in 2015. Available at: https://www.statista.com/statistics/756517/leading-countries-plasticsconsumption-europe/ [Accessed February 17, 2018].

Stubbs, W., \& Cocklin C., 2008. "Conceptualizing a "sustainability business model"." Organization \& Environment 21, no. 2, 103-127.

Su, Y., Yang, B., Liu, J., Sun, B., Cao, C., Zou, X., ... \& He, Z. 2018. Prospects for Replacement of Some Plastics in Packaging with Lignocellulose Materials: A Brief Review. BioResources, 13(2), 4550-4576.

Ten Brink P., Schweitzer J.P., Watkins E., Janssens C., De Smet M., Leslie H., Galgani F., 2018. Circular economy measures to keep plastics and their value in the economy, avoid waste and reduce marine litter. Economics Discussion Papers, (2018-3), 1-15. Open Access version: http://archimer.ifremer.fr/doc/00419/53002/

Urreaga, J. M., González-Sánchez, C., Martínez-Aguirre, A., Fonseca-Valero, C., Acosta, J., \& De la Orden, M. U., 2015. Sustainable eco-composites obtained from agricultural and urban waste plastic blends and residual cellulose fibers. Journal of Cleaner Production, 108, 377384.

Van Eygen, E., Feketitsch, J., Laner, D., Rechberger, H., Fellner, J., 2017. Comprehensive analysis and quantification of national plastic flows: The case of Austria. Resources, Conservation and Recycling, 117, pp. 183-194. Available at: http://dx.doi.org/10.1016/j.resconrec.2016.10.017 Velis, C., 2014. Global recycling markets - plastic waste: A story for one player - China. International Solid Waste Association, Vienna. Available at: https://www.iswa.org/fileadmin/galleries/Task_Forces/TFGWM_Report_GRM_Plastic_Chi na_LR.pdf

Walker, T. R., 2018. Drowning in debris: solutions for a global pervasive marine pollution problem. Marine pollution bulletin, 126, 338 .

Walker, T. R., Reid, K., Arnould, J. P., \& Croxall, J. P., 1997. Marine debris surveys at Bird Island, South Georgia 1990-1995. Marine pollution bulletin, 34(1), 61-65.

Walker, T. R., \& Xanthos, D., 2018. A call for Canada to move toward zero plastic waste by reducing and recycling single-use plastics. Resources, Conservation and Recycling, 133, 99100.

Watkins, E., Gionfra, S., Schweitzer, J-P., Pantzar, M., Janssens, C., ten Brink, P., 2017. EPR in the EU Plastics Strategy and the Circular Economy: A focus on plastic packaging. Institute for European Environmental Policy, Study report 2017. 57p., Brussels, Belgium.

Wright, S.L., Thompson, R.C., Galloway, T.S., 2013. The physical impacts of microplastics on marine organisms: a review. Environ. Pollut. 178, 483-492.

World Economic Forum, Ellen MacArthur Foundation, McKinsey and Company, 2016. The new plastics economy - Rethinking the future of plastics. Available at: https://www.ellenmacarthurfoundation.org/assets/downloads/EllenMacArthurFoundation_T heNewPlasticsEconomy Pages.pdf

Xanthos, D., \& Walker, T. R., 2017. International policies to reduce plastic marine pollution from single-use plastics (plastic bags and microbeads): a review. Marine pollution bulletin, 118(12), 17-26.

Zero Waste Europe, 2015. Redesigning Producer Responsibility - A new EPR is needed for a circular economy. Zero Waste Europe, Study report, Brussels, 2015.

Zero Waste Europe, 2017. Extended Producer Responsibility - Creating the frame for circular products. Zero Waste Europe, Position paper, Brussels, 2017.

Zubris, K. A. V. \& Richards, B. K., 2005. Synthetic fibers as an indicator of land application of sludge. Environ. Pollut. 138, 201-211. 